\title{
AMO Forcing of Multidecadal Pacific ITCZ Variability
}

\author{
AARON F. Z. LEVINE \\ NOAA/Pacific Marine Environmental Laboratory, Seattle, Washington \\ DARGAN M. W. FRIERSON \\ Department of Atmospheric Science, University of Washington, Seattle, Washington \\ MichAEL J. MCPHADEN \\ NOAA/Pacific Marine Environmental Laboratory, Seattle, Washington
}

(Manuscript received 29 November 2017, in final form 20 April 2018)

\begin{abstract}
The Atlantic multidecadal oscillation (AMO) has been shown to play a major role in the multidecadal variability of the Northern Hemisphere, impacting temperature and precipitation, including intertropical convergence zone (ITCZ)-driven precipitation across Africa and South America. Studies into the location of the intertropical convergence zone have suggested that it resides in the warmer hemisphere, with the poleward branch of the Hadley cell acting to transport energy from the warmer hemisphere to the cooler one. Given the impact of the Atlantic multidecadal oscillation on Northern Hemisphere temperatures, we expect the Atlantic multidecadal oscillation to have an impact on the location of the intertropical convergence zone. We find that the positive phase of the Atlantic multidecadal oscillation warms the Northern Hemisphere, resulting in a northward shift of the intertropical convergence zone, which is evident in the Pacific climate proxy record. Using a coupled climate model, we further find that the shift in the intertropical convergence zone is consistent with the surface energy imbalance generated by the Atlantic multidecadal oscillation. In this model, the Pacific changes are driven in large part by the warming of the tropical Atlantic and not the extratropical Atlantic.
\end{abstract}

\section{Introduction}

The Atlantic multidecadal oscillation (AMO), defined by changes in the SSTs over the North Atlantic (Enfield et al. 2001), has been implicated in large-scale, multidecadal climate variability (Kerr 2000). Over the period of instrumental record, changes in the AMO have been linked to changes in the Northern Hemisphere surface temperature (Semenov et al. 2010) and hydrology (Enfield et al. 2001). Subsequent studies with climate models have confirmed the important role of the AMO as driving these multidecadal changes (Sutton and Hodson 2005; Knight et al. 2005, 2006; Zhang and Delworth 2006). Of particular interest for this current study, the multidecadal fluctuations of the AMO have been connected to Atlantic adjacent changes in the intertropical convergence zone (ITCZ), with measured changes in the Sahel

Corresponding author: Aaron Levine, aaron.levine@noaa.gov and northeastern Brazil precipitation (Knight et al. 2006; Ruprich-Robert et al. 2017).

The impacts of the AMO on the tropical Pacific were also found by Sutton and Hodson (2005). More recent research has focused on the impact of the Atlantic SST variability globally during the last half-century, particularly accounting for multidecadal-scale changes in the SST and winds in the tropics of other ocean basins (McGregor et al. 2014; Li et al. 2015b). Physically, the changes in Atlantic SST modify the interbasin pressure differences, creating an atmospheric bridge that transmits the SST information from one basin to the next (McGregor et al. 2014; Li et al. 2015b). In the first decade-and-a-half of the 2000s, the Atlantic has warmed relative to the Pacific, leading to an increase in trade winds and a change of the Walker circulation (McGregor et al. 2014; Li et al. 2015b). The increase in trade winds is linked to a stronger equatorial cold tongue in the tropical Pacific, strengthening the cross-equatorial flow and leading to a more northward displacement of the ITCZ in the 
Pacific. Given the established changes both across the Northern Hemisphere and in the ITCZ adjacent to the Atlantic, we evaluate the changes in the ITCZ both in the Pacific and globally, with respect to our current understanding of the influences on the location of the upward branch of the Hadley circulation and the ITCZ and its relationship with the AMO.

The Hadley cell transports energy from the tropics to the extratropics through the poleward component of the flow in the upper troposphere. When the upward motion of the Hadley cell and, consequently, the ITCZ is located off the equator, there is a cross-equatorial component to the Hadley cell, which transports energy from the warmer hemisphere to the cooler hemisphere (Held 2001). With the coherent, large-scale changes to the surface temperature throughout the Northern Hemisphere, but not to the same extent in the Southern Hemisphere from the $\mathrm{AMO}$, the interhemispheric energy balance should require a northward shift of the ITCZ during its positive phase. Further, paleo records have shown that Pacific ITCZ responds to changes in Northern Hemisphere temperature (Sachs et al. 2009). Other modeling experiments have shown that the time scale of the response of the ITCZ to remotely driven changes in hemisphere energy balance is on the order of years (Fučkar et al. 2013), fast in comparison to the multidecadal time scales of the AMO. Recently, Kang et al. (2014) found that in an atmosphereonly model, the extratropical forcing does not need to be zonally symmetric to produce a zonally symmetric response in the tropical precipitation. Therefore, we expect that variability over these decadal time scales should be recordable in the tropical Pacific from variability of the AMO. We also note that with a delay of a few years, the mid-1990s AMO sign change leads the more recently observed changes to the tropical Pacific (McGregor et al. 2014; Li et al. 2015b).

Utilizing proxy data (Palmyra coral $\delta^{18} \mathrm{O}_{\mathrm{sw}}$ ), the atmospheric Twentieth Century Reanalysis (20CR) product (Compo et al. 2011), and a coupled model experiment, we will test the role of the AMO in driving the Pacific ITCZ variability via an atmospheric bridge from the Atlantic. Changes in vertical motion in the tropical Atlantic modify the Walker circulation, which will in turn impact the Hadley circulation. First, using the proxy data, we will establish a potential relationship between the tropical Pacific and the AMO. We will then use the extended reanalysis data to show that the changes in the Hadley cell in the Pacific associated with proxy record variability are consistent with the expected changes in the Hadley cell from the interhemispheric energy balance theory. Next, we will test this relationship using a coupled model experiment. Since the Hadley cell-ITCZ-hemispheric energy balance theory is based on the zonally averaged quantities, and the Pacific basin occupies approximately one-third of the global tropics, we will first examine these changes in a zonally symmetric manner before examining the role of spatial asymmetries in response to the zonally asymmetric forcing. Given the spatial variability of the impact of climate change on the North Atlantic SST (Trenberth and Shea 2006; Ting et al. 2009), we will also examine the influence of tropical versus extratropical remote forcing on the Pacific. Finally, we will discuss the implications of this study for future work on multidecadal tropical climate variability.

\section{Paleo data}

One of the challenges in understanding the long-term variability of the climate system is the lack of long records. This is especially true in the tropical Pacific. Work using fossil and modern corals on the Line Islands has, however, produced long proxy climate records in this data-sparse region. In particular, this study will take advantage of a coral record published for Palmyra with a 108-yr record with monthly data resolution (Nurhati et al. 2011). Beyond the length of the time series and location of Palmyra $\left(5^{\circ} \mathrm{N}, 160^{\circ} \mathrm{W}\right)$, another advantage of this coral record is that both strontium/calcium $(\mathrm{Sr} / \mathrm{Ca})$ and $\delta^{18} \mathrm{O}$ measurements have been taken. The $\delta^{18} \mathrm{O}$ in coral is correlated to both SST and salinity, so that by having the $\mathrm{Sr} / \mathrm{Ca}$, which responds only to SST, and $\delta^{18} \mathrm{O}$, the effects of seawater salinity as measured by $\delta^{18} \mathrm{O}_{\mathrm{sw}}$ can be isolated from the SST signal (Fairbanks et al. 1997). Previous work by Nurhati et al. (2011) explained the interannual variability of both salinity and temperature and the multidecadal variability of temperature in the corals, but was unable to explain the multidecadal variability of the $\delta^{18} \mathrm{O}_{\mathrm{sw}}$, which is a measure of salinity variability. We will focus in this study on the detrended $\delta^{18} \mathrm{O}_{\text {sw }}$ time series with the seasonal cycle removed.

\section{Pacific oceanic and atmospheric variability from proxies and reanalysis}

\section{a. Understanding salinity in the central tropical Pacific}

There are two distinct regions of surface water in the equatorial Pacific, as defined by salinity, which varies greatly across the region. The equatorial cold tongue upwells more saline water subducted from the subtropics, while in the western Pacific warm pool and in the atmospheric convergence zones north and south of the equator, significant amounts of precipitation freshen the surface water. The dramatic zonal and meridional contrasts in salinity that occur can be used to mark the 

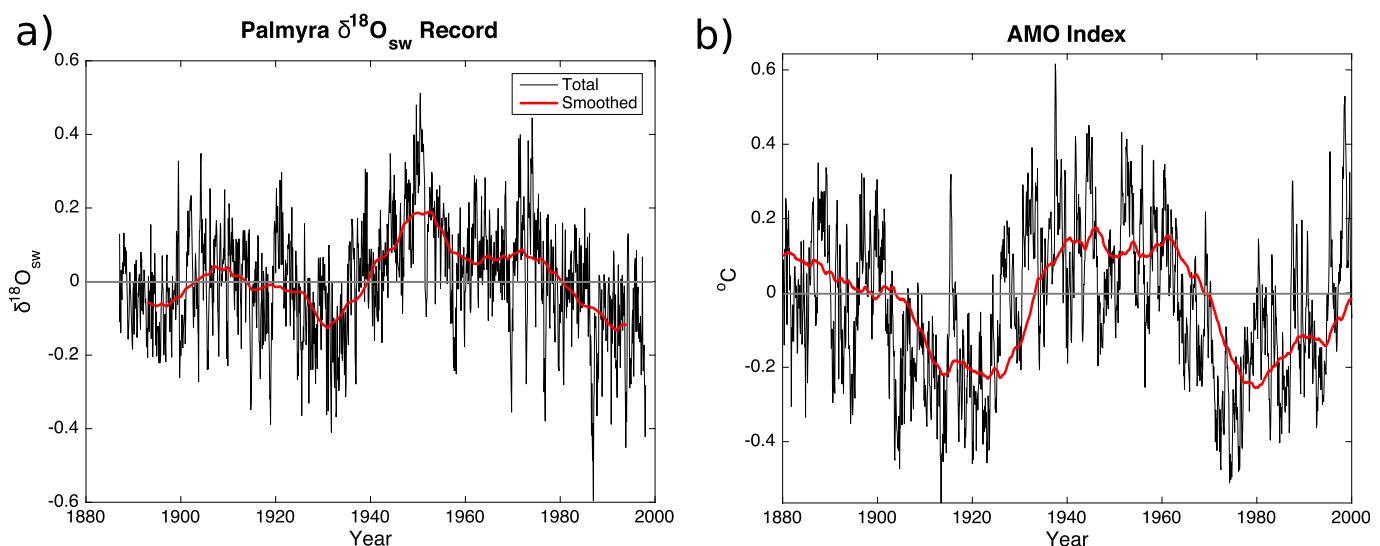

FIG. 1. Monthly resolved and 11-yr running mean of the (a) $\delta^{18} \mathrm{O}_{\mathrm{sw}}$ record from Palmyra and (b) AMO index.

extent of the warm pool and cold tongue (Picaut et al. 2001). In the central Pacific, these salty cold tongue waters are advected meridionally well into the north equatorial countercurrent until a dramatic freshening, occurring around $7^{\circ} \mathrm{N}$ (Delcroix et al. 2007). This leaves the Palmyra Atoll $\left(5^{\circ} \mathrm{N}\right)$ in the region of salty water. As noted by Nurhati et al. (2011), there is multidecadal variability in the $\delta^{18} \mathrm{O}_{\mathrm{sw}}$ record, representing changes in the salinity of the seawater that the coral grew in (Fig. 1a). Nurhati et al. (2011) were not able to correlate the $\delta^{18} \mathrm{O}_{\text {sw }}$ to any known indices of Pacific multidecadal variability. More recently, Zanchettin et al. (2016) found in model simulations that the Atlantic SSTs lead equatorial Pacific salinity by approximately 10 years. Using the coral data, we similarly find that the AMO index leads the $\delta^{18} \mathrm{O}_{\text {sw }}$ time series by approximately 10 years in both the 11-yr smoothed ( $r=0.8,90 \%$ statistical significance) and unsmoothed monthly time series $(r=0.5)$ (Fig. 2). The positive correlation indicates that the positive AMO phase leads to more saline water around Palmyra, in agreement with the modeling study of Zanchettin et al. (2016). Additionally, salinity lagging the AMO by a decade while leading the interdecadal Pacific oscillation (IPO) by less than 5 years is similar to the relationship between the Atlantic and extratropical Pacific found by Zhang and Delworth (2007).

Warm tropical Atlantic SSTs have been shown to increase the trade wind strength and cold tongue strength in the tropical Pacific (McGregor et al. 2014; Li et al. 2015b). The increased upwelling in the Pacific cold tongue during a positive AMO phase results in saltier water in the cold tongue, which is then advected to Palmyra. Locally, an increase in wind speed associated with stronger trade winds would be expected to result in more evaporation, also producing a saltier ocean around Palmyra during the positive phase of the AMO. Thus, changes in Walker circulation lead to an altered ocean salinity in the region of Palmyra through two mechanisms that both change the
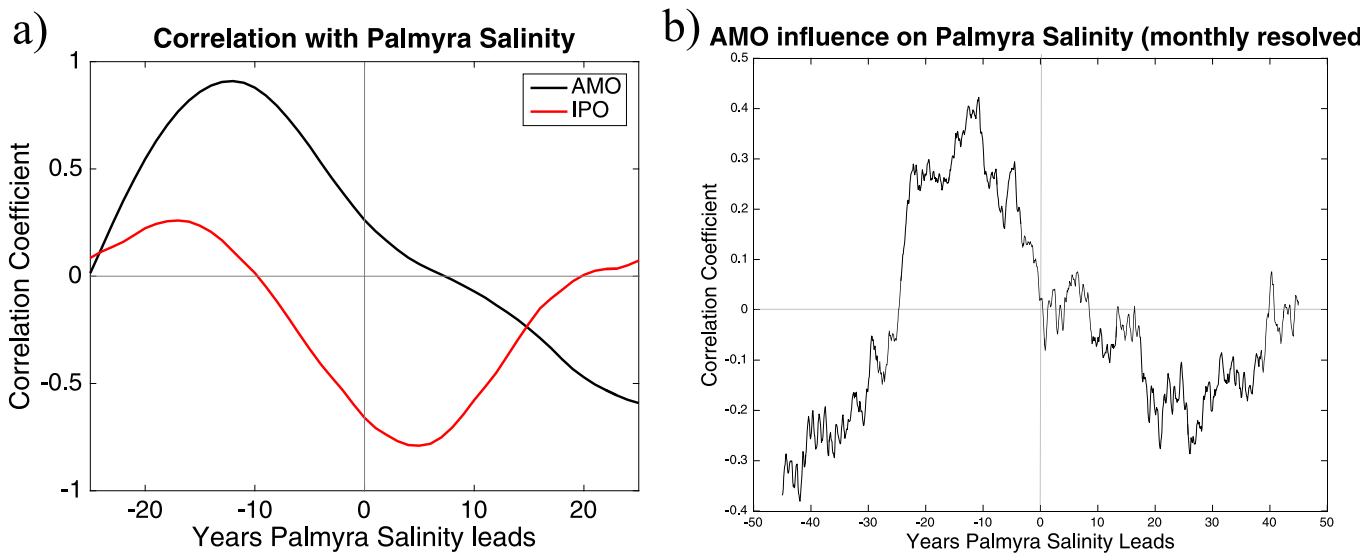

FIG. 2. (a) Lead-lag correlations for Palmyra $\delta^{18} \mathrm{O}_{\text {sw }}$ on $11-\mathrm{yr}$ windows with the AMO and IPO indices. The AMO leads $\delta^{18} \mathrm{O}_{\mathrm{sw}}$ by approximately $10 \mathrm{yr}$ with a correlation exceeding $r=0.8$. (b) Correlation of monthly resolved $\delta^{18} \mathrm{O}_{\text {sw }}$ and AMO time series. The AMO leads by $10 \mathrm{yr}$ with significant correlations. 

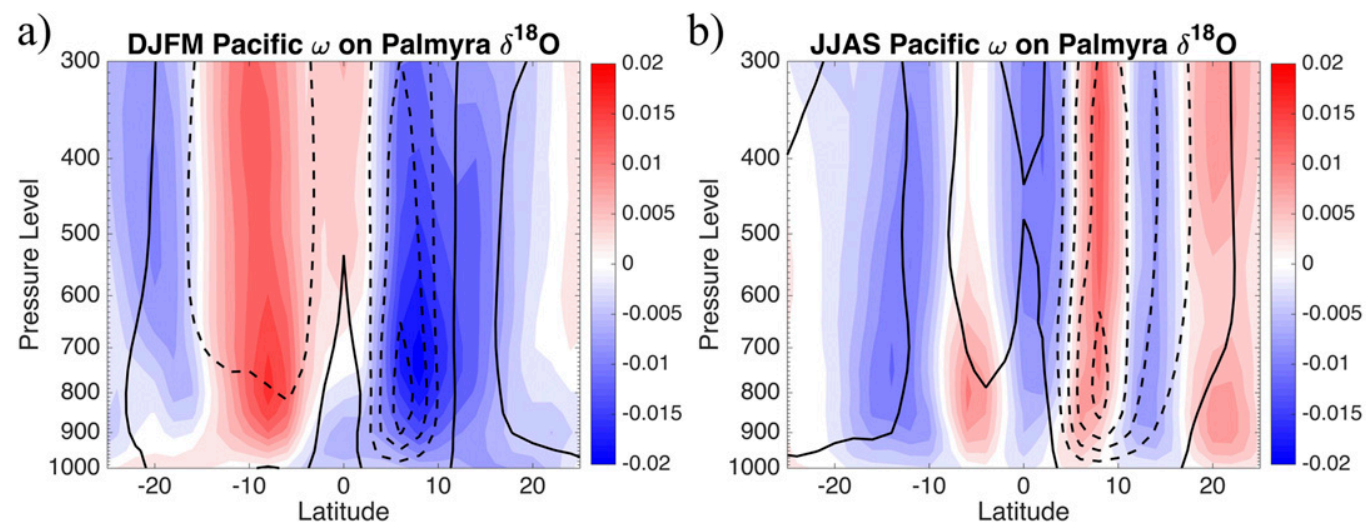

FIG. 3. Regression of (a) December-March (DJFM) and (b) June-September (JJAS) tropical Pacific zonally averaged $\omega$ on $\delta^{18} \mathrm{O}_{\text {sw. }}$. Contours (solid positive, dashed negative) are the mean $\omega$ from 20CR, with a contour interval of $0.015 \mathrm{hPa} \mathrm{s}^{-1}$ and negative values representing upward motion. Values are shaded where the regression is at least $90 \%$ significant.

salinity in the same direction. Opposite tendencies occur during periods of weaker Walker circulation.

\section{b. Atmospheric circulation}

As noted by McGregor et al. (2014) and Li et al. (2015b), the stronger trade winds that we have previously argued drive the enhanced salinity in the Palmyra coral record are forced by changes in the SST gradient between the tropical Atlantic and the equatorial Pacific. With these changes to the equatorial cold tongue, we expect to see changes in the Hadley cell; specifically, with a stronger cold tongue, we expect the rising branch of the Hadley cell to be farther off the equator. To check this expectation, we regress the atmospheric vertical motion in the reanalysis on the Palmyra $\delta^{18} \mathrm{O}_{\mathrm{sw}}$ record. We find that saltier conditions at Palmyra are associated with a northward shift of the vertical motion in the atmosphere, a measure for the location of the ITCZ, in both the boreal winter and summer over the Pacific (Fig. 3). The associated changes in vertical pressure velocity $\omega$ that we find are approximately $10 \%$ of the mean vertical velocities in the upward branch of the Hadley cell, corresponding to a northward shift of the ITCZ, which occurs in all seasons. The meridional location of the ITCZ has been shown to be related to the interhemispheric energy balance (Held 2001; Frierson and Hwang 2012). In response to the positive phase of AMO, the North Atlantic Ocean fluxes more latent and sensible heat into the atmosphere, and vice versa during a negative phase of the AMO. This theory suggests that the ITCZ should shift poleward in response to the additional warming of the Northern Hemisphere since the energy transport is dominated by the upper branch of the Hadley cell (Held 2001), allowing for the atmosphere to transfer more heat to the cooler hemisphere. So, the theory predicts that in response to the warming in the Atlantic, the Pacific ITCZ shifts farther north, leading to a more northerly ITCZ and a stronger cold tongue and producing a more saline coral record at Palmyra, consistent with our findings.

\section{Model experiment}

\section{a. Experimental design}

To augment the observational analysis, we complete a 500-yr simulation of Geophysical Fluid Dynamics Laboratory's (GFDL) Climate Model version 2 (CM2) with Modular Ocean Model version 4.1(MOM4.1) at coarse resolution (CM2Mc) (Galbraith et al. 2011), where the SSTs in the North Atlantic $\left(0^{\circ}-70^{\circ} \mathrm{N}, 10^{\circ}-18^{\circ} \mathrm{W}\right)$ are relaxed to the model's monthly climatology plus a $50-\mathrm{yr}$

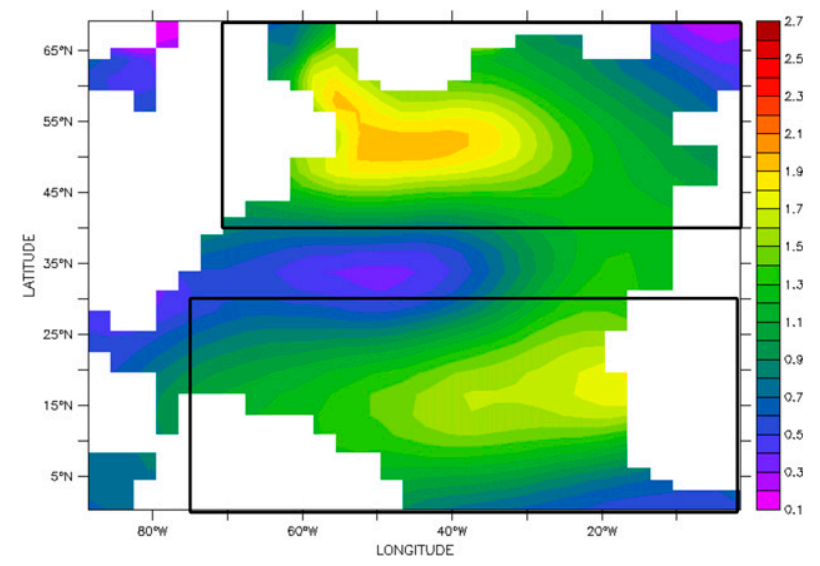

FIG. 4. The AMO SST temperature pattern used to force the coupled model. The pattern varies sinusoidally on a 50 -yr time scale. Continental boundaries on the model grid are represented in white. The boxes indicate the subregions used in the tropical- and extratropical-only forced experiments. 
a)

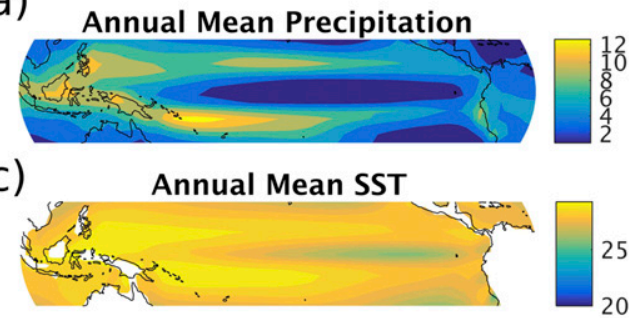

e)

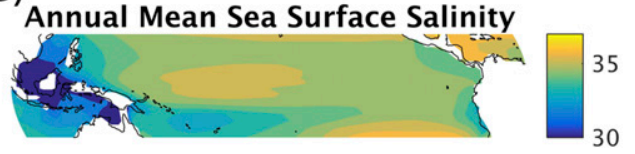

b)

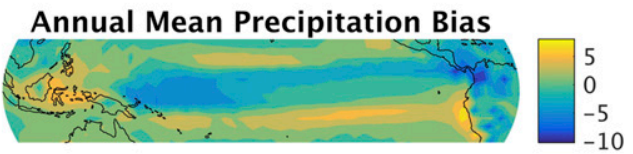

d)

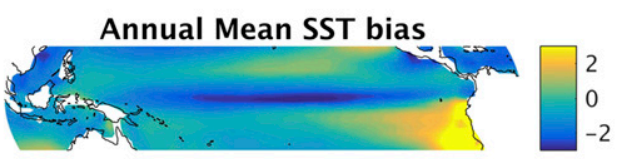

f)

Annual Mean Sea Surface Salinity Bias (PSU)

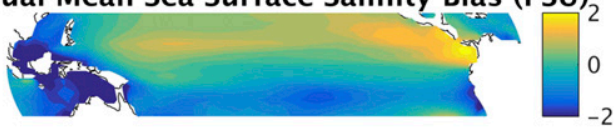

FIG. 5. Coupled model (a),(c),(e) annual mean and (b),(d),(f) bias for (a),(b) precipitation (mm day ${ }^{-1}$ ); (c),(d) SST $\left({ }^{\circ} \mathrm{C}\right)$; and (e),(f) sea surface salinity (psu). The reanalysis fields are taken from SODA for SST and salinity and 20CR for precipitation.

sinusoidally varying AMO anomaly with a 2-day relaxation time. The AMO anomaly is calculated by regressing the Simple Ocean Data Assimilation (SODA) version 2.2.4 (Giese and Ray 2011) SSTs on the Earth System Research Laboratory's AMO index (Fig. 4). The model ocean is not altered in the other regions. The atmospheric component of the model has $3.5^{\circ} \times 3^{\circ}$ horizontal resolution with 24 vertical levels. The oceanic component has nominal $3^{\circ}$ ocean resolution, increasing to $0.6^{\circ}$ at the equator, and 28 vertical levels, including five in the upper $50 \mathrm{~m}$. Composites are used to compare the positive AMO phase to the negative AMO phase by averaging the period from five years before to five years, following prescribed sinusoidal AMO peak across all 10 peaks in the simulation to determine the positive AMO phase. A similar averaging is done for the negative phase of the AMO compositing across troughs. We note that recent research has questioned if the AMO is better characterized as red noise variability as opposed to an oscillation (Clement et al. 2015). The choice of an oscillation here is a matter of expediency. Given that the atmosphere responds quickly to the large-scale changes in forcing, we expect that the differences between positive and negative AMO phases should persist, regardless of the specific character of the AMO variability.

\section{b. Model climatology}

The model annual means and biases from reanalysis for precipitation, SST, and sea surface salinity in the tropical Pacific are shown in Fig. 5. Like many coupled climate models, CM2Mc struggles to correctly simulate precipitation and SST in the tropical Pacific. The precipitation has a double ITCZ bias, with a stronger and more zonal SPCZ than observed extending across the western and central Pacific. Correspondingly, the model SST has an overly strong equatorial cold tongue that extends too far to the west. Along the South American coast, the SST also shows a substantial warm bias, and coastal precipitation is increased as well. Biases in precipitation largely account for the biases in the sea surface salinity field, with generally fresher water in the Southern Hemisphere and saltier water in the Northern Hemisphere. The waters around the Maritime Continent are also fresher than reanalysis. Despite these biases, the model mean state has an equatorial cold tongue that is saltier than the western Pacific warm pool and an off-equatorial ITCZ, allowing us to examine the role of the Atlantic warming on the Pacific ITCZ. We expect that some of these biases would be lessened in higher-resolution simulations, particularly in the atmosphere, and that higher-resolution simulations should be run when the resources are available (Landu et al. 2014).

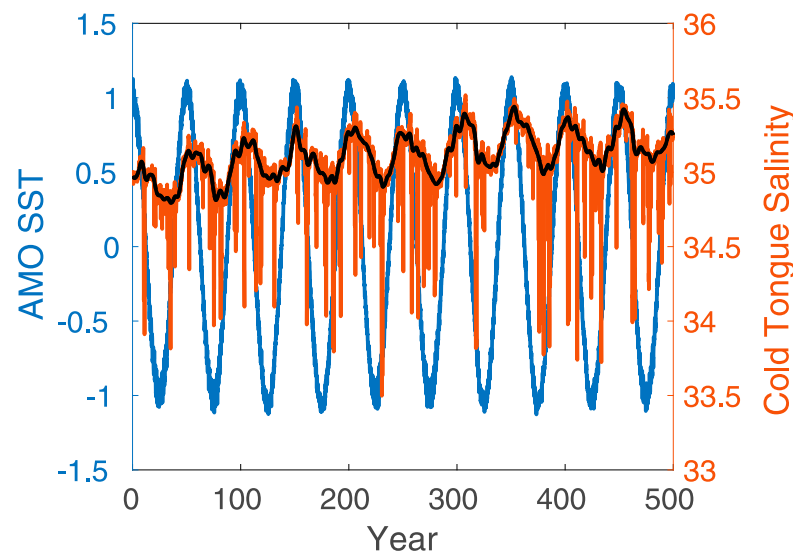

FIG. 6. The AMO SSTs (blue; ${ }^{\circ} \mathrm{C}$ ), monthly (orange; psu), and 121-month robust locally estimated scatterplot smoothing (LOESS) filter smoothed (black; psu) ocean surface salinity within $3^{\circ} \mathrm{S}-3^{\circ} \mathrm{N}, 160^{\circ} \mathrm{E}-160^{\circ} \mathrm{W}$ from the whole AMO experiment. The surface salinity lags the AMO SSTs by approximately $10 \mathrm{yr}$, like the coral $\delta^{18} \mathrm{O}$ record suggests. 
a)

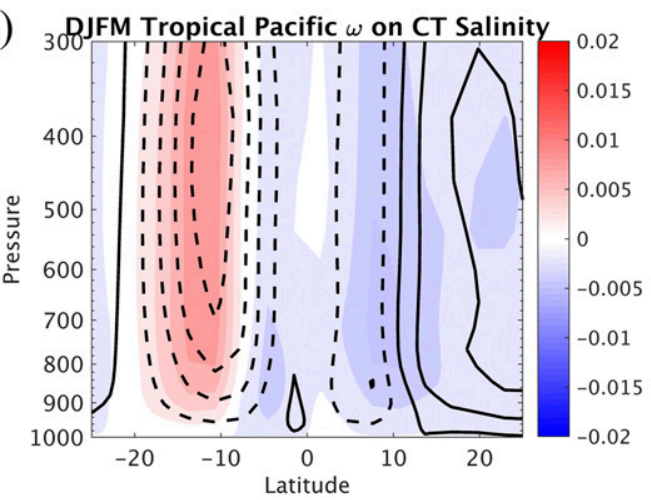

c)

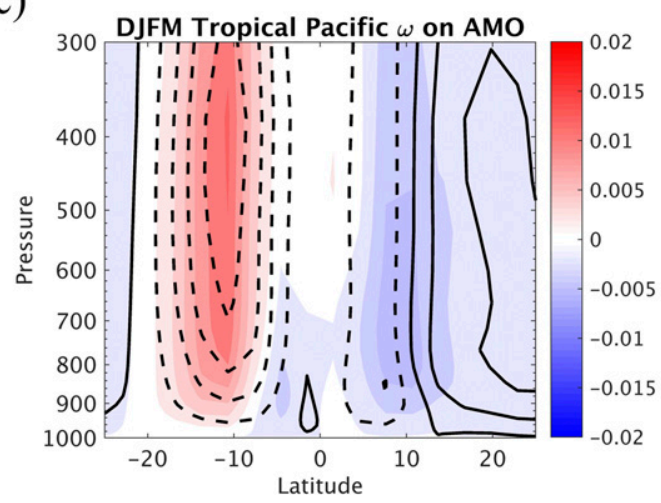

b)

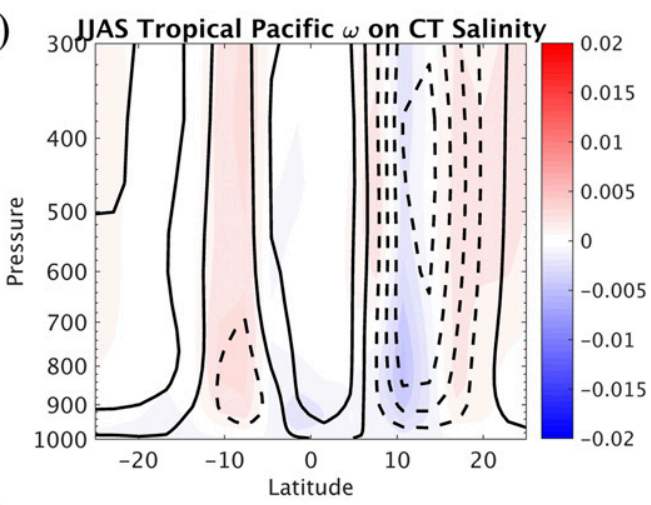

d)

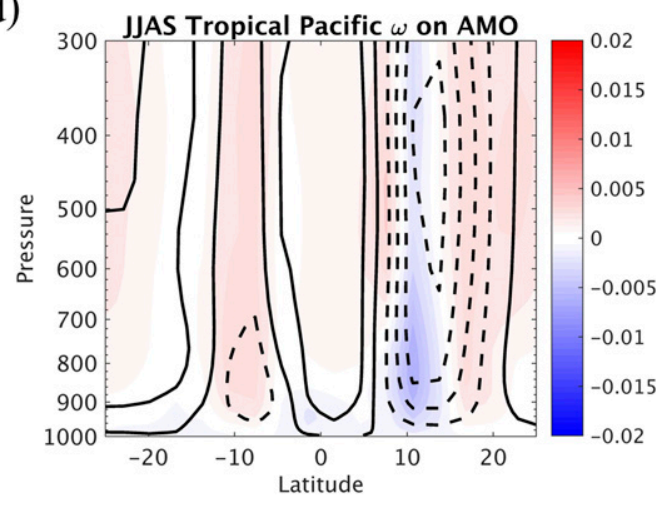

FIG. 7. Regression of (a),(c) DJFM and (b),(d) JJAS tropical Pacific zonally averaged $\omega$ on sea surface salinity at the cold tongue edge and AMO SSTs, respectively. Contours (solid positive, dashed negative) are the mean from the AMO simulation, with a contour interval of $0.015 \mathrm{hPa} \mathrm{s}^{-1}$. Values are shaded where the regression is at least $95 \%$ significant.

\section{c. ITCZ changes}

We first check that the model sea surface salinity in the region of Palmyra, at the equatorial cold tongue's western edge, follows the AMO. The salinity is strongly variable at the monthly time scale, but the decadal-scale changes in the salinity show a significant periodicity of approximately $50 \mathrm{yr}$ and lag the AMO SSTs by approximately $10 \mathrm{yr}$ (Fig. 6). This is in agreement with both the coral $\delta^{18} \mathrm{O}_{\mathrm{sw}}$ results from Palmyra and the results of Zanchettin et al. (2016). Despite the double ITCZ bias in the model, when salinity is elevated in the central equatorial Pacific, following the positive phase of the AMO, the Pacific $\left(120^{\circ} \mathrm{E}-80^{\circ} \mathrm{W}\right)$ Hadley cell shifts northward in all seasons (Figs. 7a,b). These results are not strongly dependent on the choice of the longitudinal end points of the averaging. During the boreal winter, the dominant southern branch of the ITCZ (a model bias) has the greatest decrease in vertical velocity, particularly along its southern flank, with a slight increase in vertical velocity along its northern flank. The previously mostly nonexistent northern branch of the ITCZ has a significant increase in vertical velocity along the northern edge of the rising motion. This expands the region of low-level rising motion northward and extends the region of significant vertical motion much higher in the troposphere than before, indicating much more significant vertical motion in the Northern Hemisphere ITCZ. The boreal summer tropical Pacific vertical velocities show similar increases in descending motion in the Southern Hemisphere and increases in the Northern Hemisphere as during the boreal winter, although the changes are not as large as in the boreal winter. The changes in vertical velocity are similar if not slightly stronger when regressed on the AMO SSTs (Figs. 7c,d). This suggests that the shifts in vertical motion and the ITCZ are responsive to the AMO SSTs, which in turn lead to the changes in sea surface salinity. The delay in the sea surface salinity response, when compared with the atmospheric vertical velocity, suggests that the changes in the sea surface salinity are driven by changes to ocean circulation, as suggested by Zanchettin et al. (2016).

The model reproduces the changes in salinity in the tropical Pacific that we find in the proxy data in response to the AMO forcing, and we now evaluate the response 


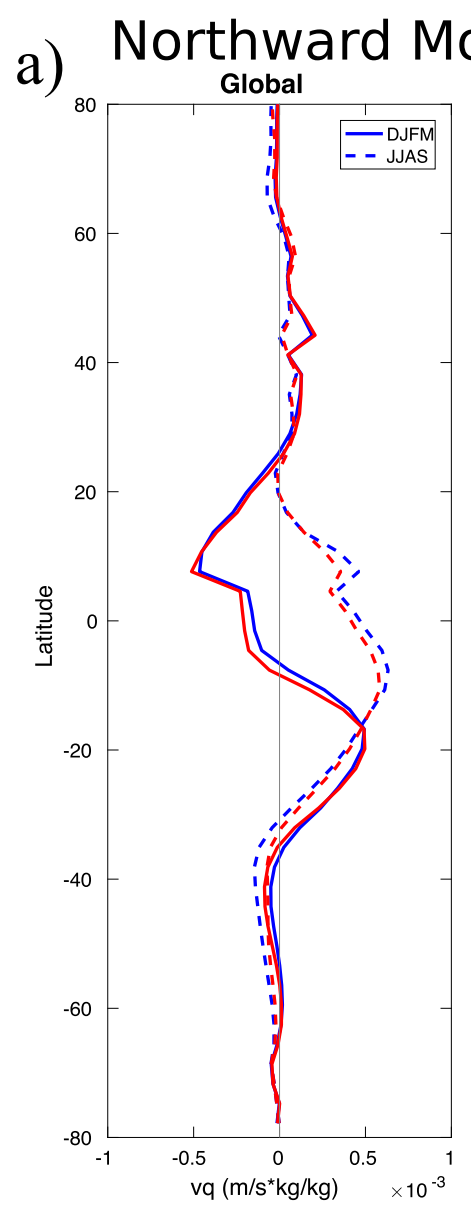

oisture Transport

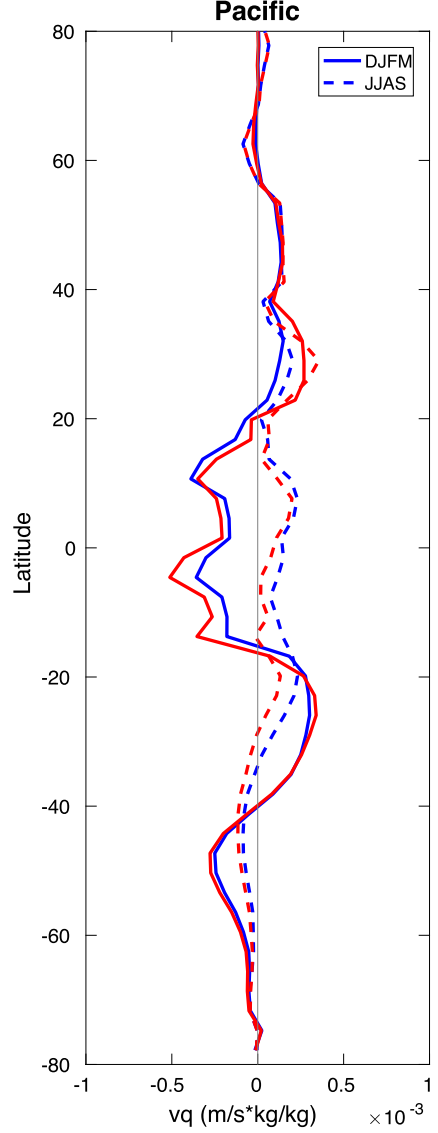

b)

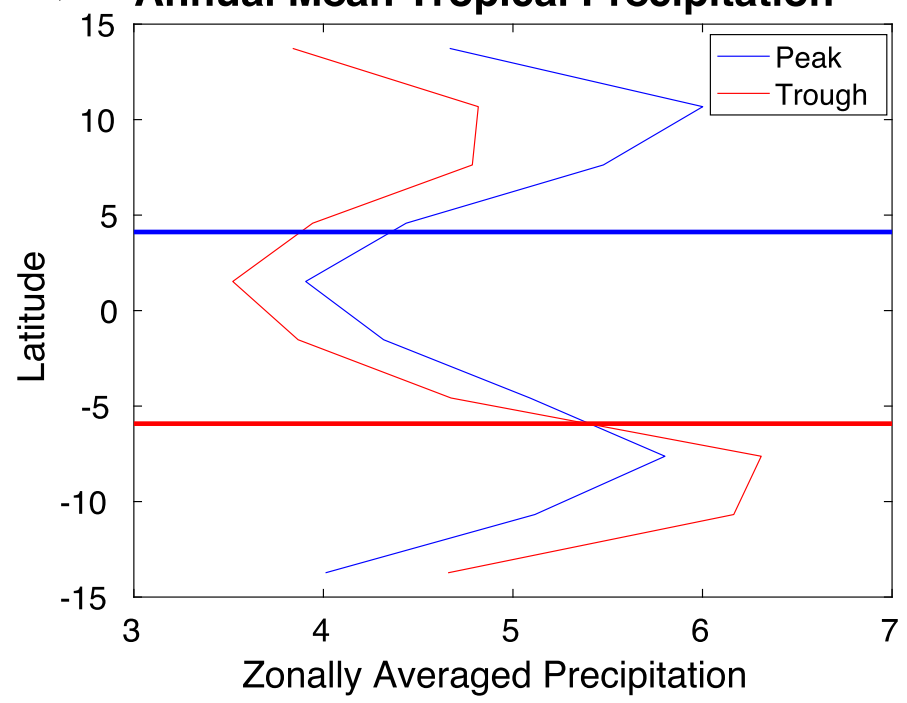

FIG. 8. (a) Lower-atmospheric meridional specific humidity transport during boreal winter (DJFM, dashed) and summer (JJAS, solid) during the $\pm 5 \mathrm{yr}$ before and after the max (red) or min (blue) of the AMO. Globally averaged is on the left, and Pacific-only is on the right. (b) Global zonal average tropical precipitation for the annual mean precipitation $\left(\mathrm{mm} \mathrm{day}^{-1}\right)$ from $\pm 5 \mathrm{yr}$ before and after the max (red) or min (blue) of the AMO. The horizontal solid lines represent the centroid of precipitation, which shifts approximately $10^{\circ}$ of latitude in response to the AMO forcing, in agreement with the changes in hemispheric energy balance. 
TABLE 1. Hemispheric-averaged atmospheric energy balance for all years, AMO peak positive phase years, and AMO minimum negative phase years $\left(\mathrm{W} \mathrm{m}^{-2}\right)$. The bottom row is the difference Northern Hemisphere minus Southern Hemisphere.

\begin{tabular}{lrcc}
\hline \hline & All years & AMO positive & AMO negative \\
\hline Global & 0.2 & 0.2 & 0.2 \\
Northern Hemisphere & -0.4 & 0.5 & -1.3 \\
Southern Hemisphere & 0.8 & -0.1 & 1.8 \\
Difference & -1.2 & 0.6 & -3.1 \\
\hline
\end{tabular}

of the ITCZ to the AMO. The changes to the crosshemispheric flow in the tropical Pacific can also be seen in the low-level moisture flux, indicating an enhancement of the northward flow in the surface branch of the Hadley circulation (Fig. 8a). With the double ITCZ bias in the model, there are southward transports in the boreal winter and northward transports in the boreal summer in the tropical Pacific. During the positive phase of the AMO, the northward transport of moisture across the equator is greater in all seasons than during the negative phase of the AMO, supporting the increased Northern Hemisphere ITCZ. Similar tendencies occur with the opposite sign during the negative phase of the AMO. This particularly holds in examining the Pacific basin, where the shifts in vertical motion are supported by changes in moisture convergence, as opposed to the Atlantic, where the changes are partially imposed by the experimental design. The shifting of vertical motion and the additional transport of moisture across the equator are consistent with the interhemispheric atmospheric transport of energy and the shift of the ITCZ into the warmer hemisphere. To quantify the impact of the change in the atmospheric energy balance on ITCZ location, we first calculate the centroid of precipitation as defined by Frierson and Hwang (2012). The centroid shifts approximately $10^{\circ}$ latitude northward during the peak of the AMO positive phase, compared to the AMO negative phase (Fig. 8b). We compare the shift in the centroid of precipitation to the atmospheric energy balance in the two hemispheres based on AMO phase (Table 1). The hemispheric energy balance is calculated by summing the net energy flux into the atmosphere at the Earth's surface and top of atmosphere over both the Northern and Southern Hemispheres and finding the imbalance between the hemispheres. We find that the hemispheric energy imbalance between the positive and negative AMO phases is approximately $3.5 \mathrm{~W} \mathrm{~m}^{-2}$ when the precipitation centroid is shifted approximately $10^{\circ}$ latitude, in agreement with the fit from Donohoe et al. (2014).

Recent work has emphasized that the ocean also plays a role to maintain the energy balance between the two hemispheres (Frierson et al. 2013; Marshall et al. 2014; Kay et al. 2016). Many of the previous studies have

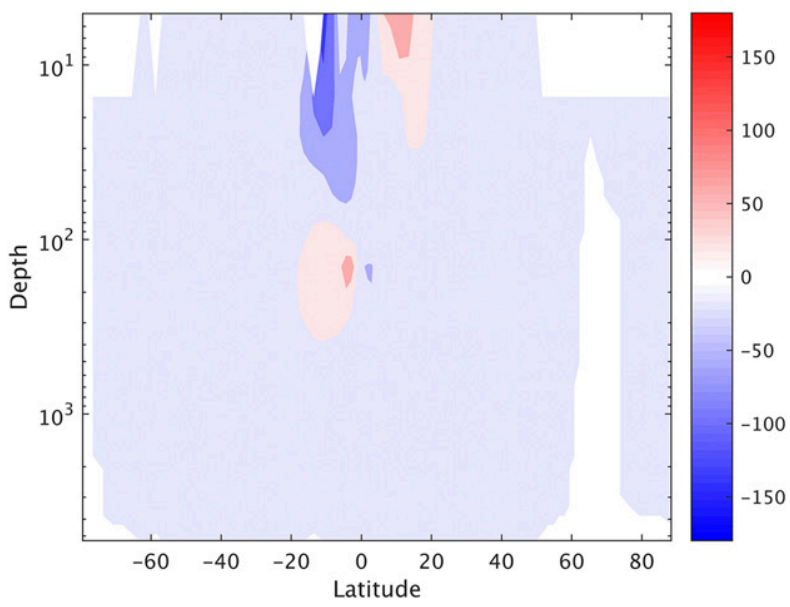

FIG. 9. Zonally averaged model-calculated oceanic meridional heat transport $(\mathrm{ZJ})$ in the Pacific regressed on the AMO. We see that the ocean acts to also compensate for the hemispheric energy imbalance. Values are shaded where the regression is at least $95 \%$ significant. Depth is in meters.

examined the changes in the ITCZ from extratropical forcing in models with slab ocean (i.e., Frierson and Hwang 2012). Because of the imposed SSTs in the Atlantic, we only examine the ocean heat transport response in the Pacific Ocean to the imposed AMO SSTs. We see that in the positive AMO phase, the Pacific Ocean transports less heat to the Northern Hemisphere (Fig. 9), acting in concert with the atmosphere to keep the two hemispheres energetically balanced. In the tropics, the poleward ocean heat transport increases in the upper $50 \mathrm{~m}$ more in the Southern Hemisphere than in the Northern Hemisphere. There is also an increase in the transport of cold Antarctic Bottom Water crossing the equator from the Southern Hemisphere to the Northern Hemisphere in the deep ocean. Likewise, during the negative phase of the AMO, the ocean transport reverses, with the Southern Hemisphere transporting less heat poleward in the upper ocean and less cold water being transported across the equator in the deep ocean. This likely moderates the change in the atmospheric circulation in response to the energy imbalance, compared with previous studies that do not include a full ocean model (cf. He and Soden 2016; Trossman et al. 2016; Delworth et al. 2017). However, as noted earlier, the precipitation change that we find is in agreement with the findings of Donohoe et al. (2014), who used results from fully coupled GCMs to look at changes to the precipitation in response to the seasonal cycle of forcing.

\section{d. Zonally asymmetric changes}

Many previous studies on hemispheric energy balance and the location of the ITCZ have focused more closely on the zonally symmetric changes in the Hadley cell in 
a)

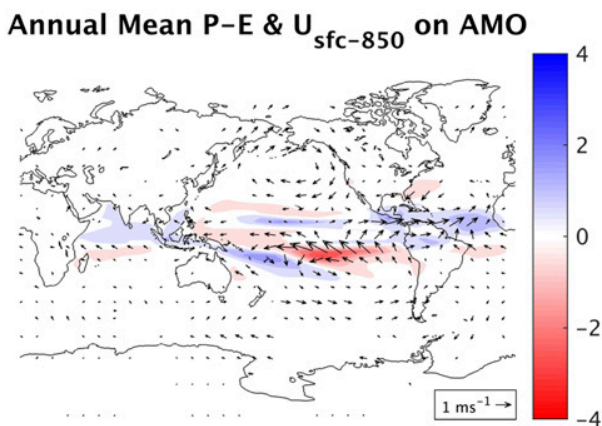

c)

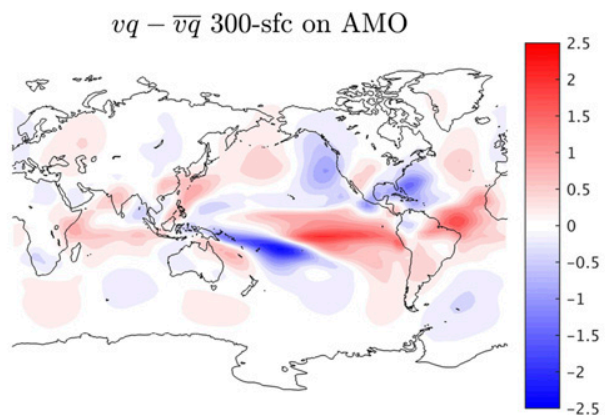

e)

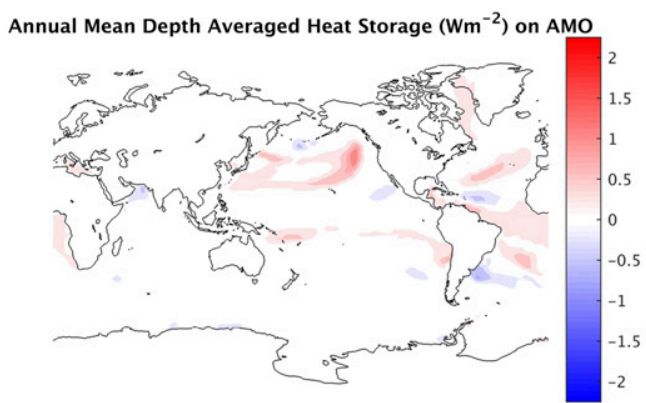

b)

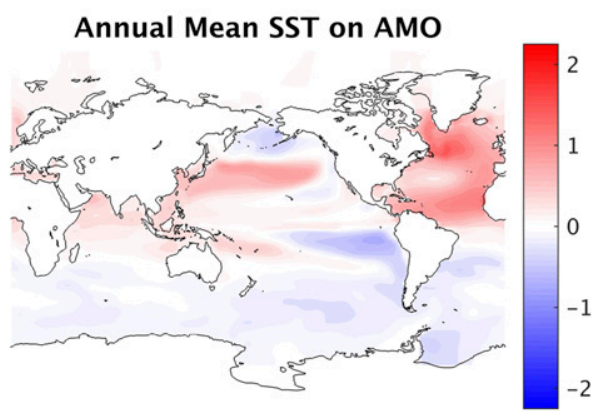

d)

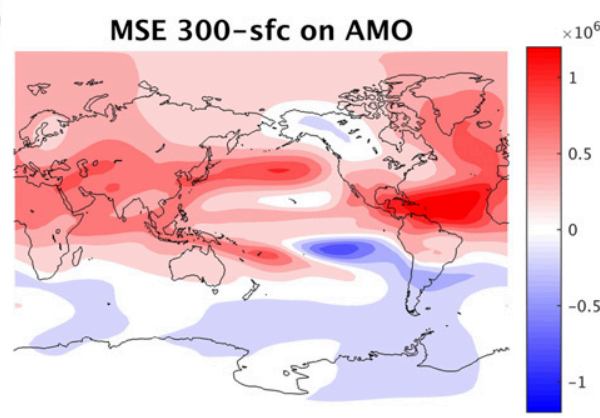

FIG. 10. Annual mean (a) $P-E\left(\mathrm{~mm} \mathrm{day}^{-1}\right)$ and surface-850-hPa winds, (b) SST $\left({ }^{\circ} \mathrm{C}\right)$, (c) anomalous meridional moisture transport $\left(\mathrm{m} \mathrm{s}^{-1} \mathrm{~kg} \mathrm{~kg}^{-1}\right)$ integrated from the surface to $300 \mathrm{hPa}$, (d) moist static energy (J), and (e) depthaveraged ocean heat storage regressed on AMO. Values are shaded where the regression is at least $95 \%$ significant.

response to the changes in the hemispheric energy balance. These sets of experiments give us the opportunity to better explore the spatial responses both to the asymmetries in the more complex case from the regionally confined heating of the AMO and the continents.

During the positive phase of the AMO, the amount of precipitation in the Southern Hemisphere is greatly reduced, and in the boreal summer, the Northern Hemisphere ITCZ shows a significant increase in precipitation, with opposite tendencies occurring during the negative phase of the AMO (Fig. 10a). There are large reductions of precipitation in the zonally elongated Southern Hemisphere ITCZ and an additional impact of tilting the band of heavy precipitation poleward as it goes farther east. These changes in precipitation are in agreement with the expected changes to the Pacific ITCZ with the previous analysis. The changes in the Pacific precipitation are supported by enhanced southeast trade winds and cross-equatorial flow. We also note that there is a notable increase in the tropical Atlantic precipitation during the positive phase of the AMO, in agreement with the local and remote effects of Atlantic SST increases found by McGregor et al. (2014) and Li et al. (2015b). Furthermore, the changes in the lower-tropospheric winds reflect the previous findings, suggesting an increase in Walker circulation because of a warmer Atlantic. Other remotely forced changes to the mean surface circulation are also apparent, including a reduction in strength of the Aleutian low.

These remote circulation changes can be further examined in the changes to the anomalous meridional moisture transport (Fig. 10c). Significant decreases in 
a) Annual Mean $Q_{\text {net }}$ on AMO

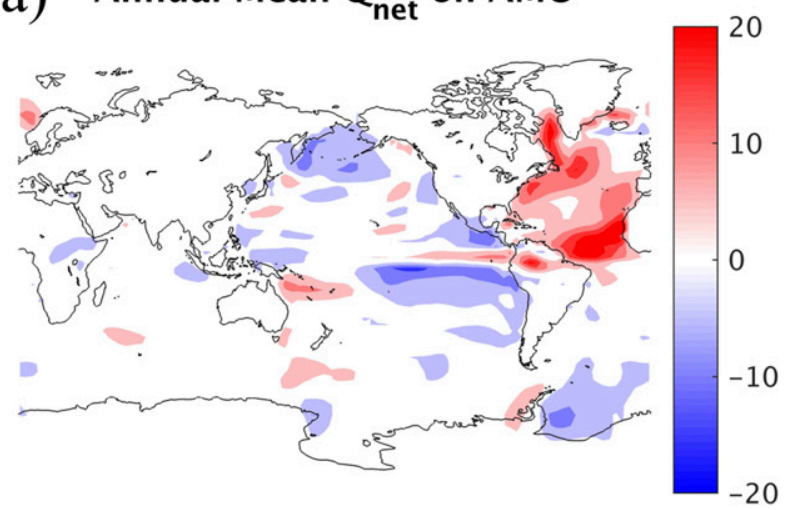

b) Annual Mean $Q_{\text {sfc }}$ on AMO

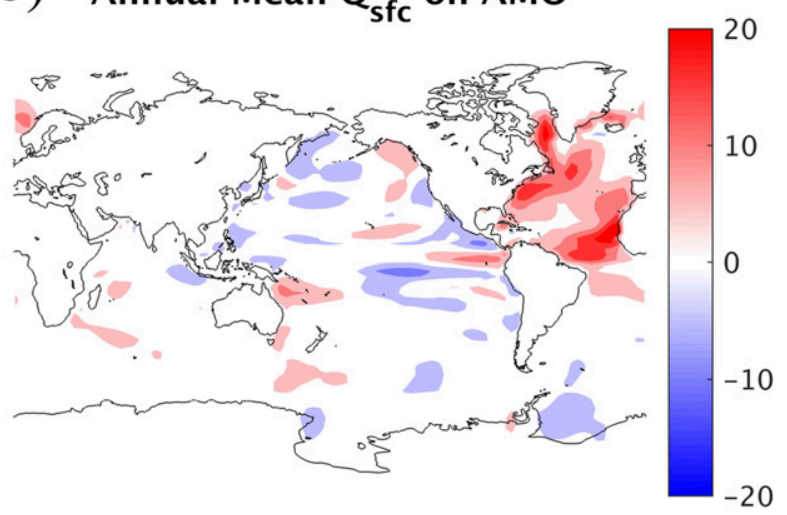

c) Annual Mean $Q_{T O A}$ on $A M O$

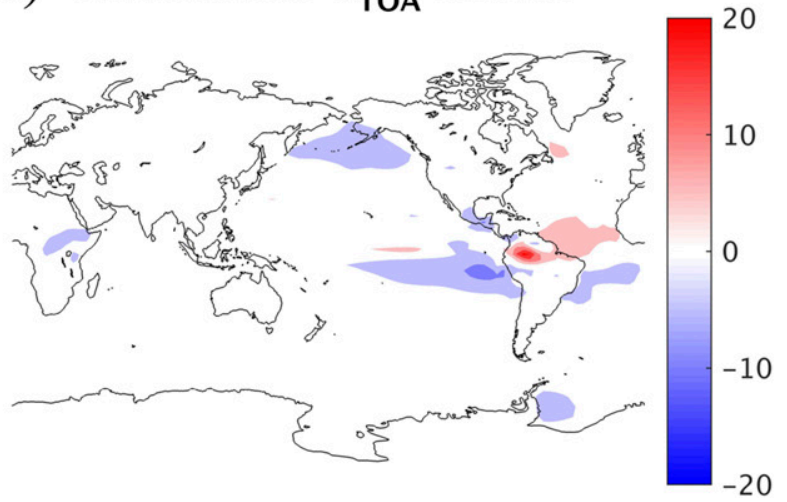

FIG. 11. Regression of (a) net atmospheric heat flux $Q_{\text {net }}\left(\mathrm{W} \mathrm{m}^{-2}\right)$, (b) net surface energy flux $Q_{\text {sfc }}\left(\mathrm{W} \mathrm{m}^{-2}\right)$, and (c) net top-of-theatmosphere energy flux $Q_{\mathrm{TOA}}\left(\mathrm{W} \mathrm{m}^{-2}\right)$ on the AMO. The total net heat flux is dominated by the changes to the surface terms. Values are shaded where the regression is at least $95 \%$ significant.

the moisture transport can be seen in the eastern North Pacific, with a corresponding increase in the western North Pacific corresponding with the reduced strength of the Aleutian low. Elsewhere in the Northern Hemisphere, the Caribbean anticyclone is strengthened by the moisture flux changes, in agreement with previous Atlantic water-hosing modeling studies (Timmermann et al. 2007). In the Southern Hemisphere, the eddy fluxes are consistent with the Pacific-South America stationary waves and the role of the tropics in forcing the multidecadal-scale variability of the southern annular mode (Wang et al. 2010; Ding et al. 2012; Li et al. 2015a).

Atmospheric circulation changes both respond to and cause changes in the atmospheric energy budget. We consider the spatial distribution of the net atmospheric energy changes (Fig. 11a). We find that large contributions of the net heating to the atmosphere occur in the Northern Hemisphere in the Atlantic Ocean. In many places, these increases in atmospheric energy uptake are collocated with the forced SST changes. In the Pacific, the changes are smaller and less spatially homogeneous. In the tropics, we find an increase of downward flux, collocated with the region of the Southern Hemisphere ITCZ that weakens, and decreases of downward energy flux in regions where precipitation increases in the Northern Hemisphere. The equatorial cold tongue has decreased downward flux as well. During the positive AMO phase, there is a net positive flux of energy into the atmosphere in the North Atlantic balanced by the atmosphere losing energy elsewhere. The energy gain is almost entirely from the surface term (Fig. 11b), while the top of atmosphere term produces mostly localized cooling (Fig. 11c).

We decompose the net surface flux into its component fluxes (Fig. 12). We find that the bulk of the change to the fluxes are a balance between the net shortwave and latent heat (Figs. 12a,c), while changes in the sensible and net longwave are mostly smaller and local (Figs. 12b,d). The most significant changes to the latent heating occur in the Atlantic where the SSTs are altered. In the tropical regions, there is also appreciable shortwave forcing resulting from changes in cloud types. In the tropical Pacific, for example, decreases in net surface shortwave are collocated with decreases in local precipitation minus evaporation $(P-E)$ and are related to changes in the cloud type and suppression of the double ITCZ. The changes to the latent heating reflect similar shifts in the ITCZ and also the enhanced upwelling in the cold tongue, driven by the stronger cross-equatorial winds and reflected in the higher values of sea surface salinity previously discussed. The changes in the energy balance in the North Pacific-increases in net surface shortwave and longwave and a decrease in latent heatsuggest an increase in SSTs near the Aleutian Islands and a decrease in surface winds, all consistent with the reduced strength of the Aleutian low. These mechanisms explain the reduction in ocean heat storage 

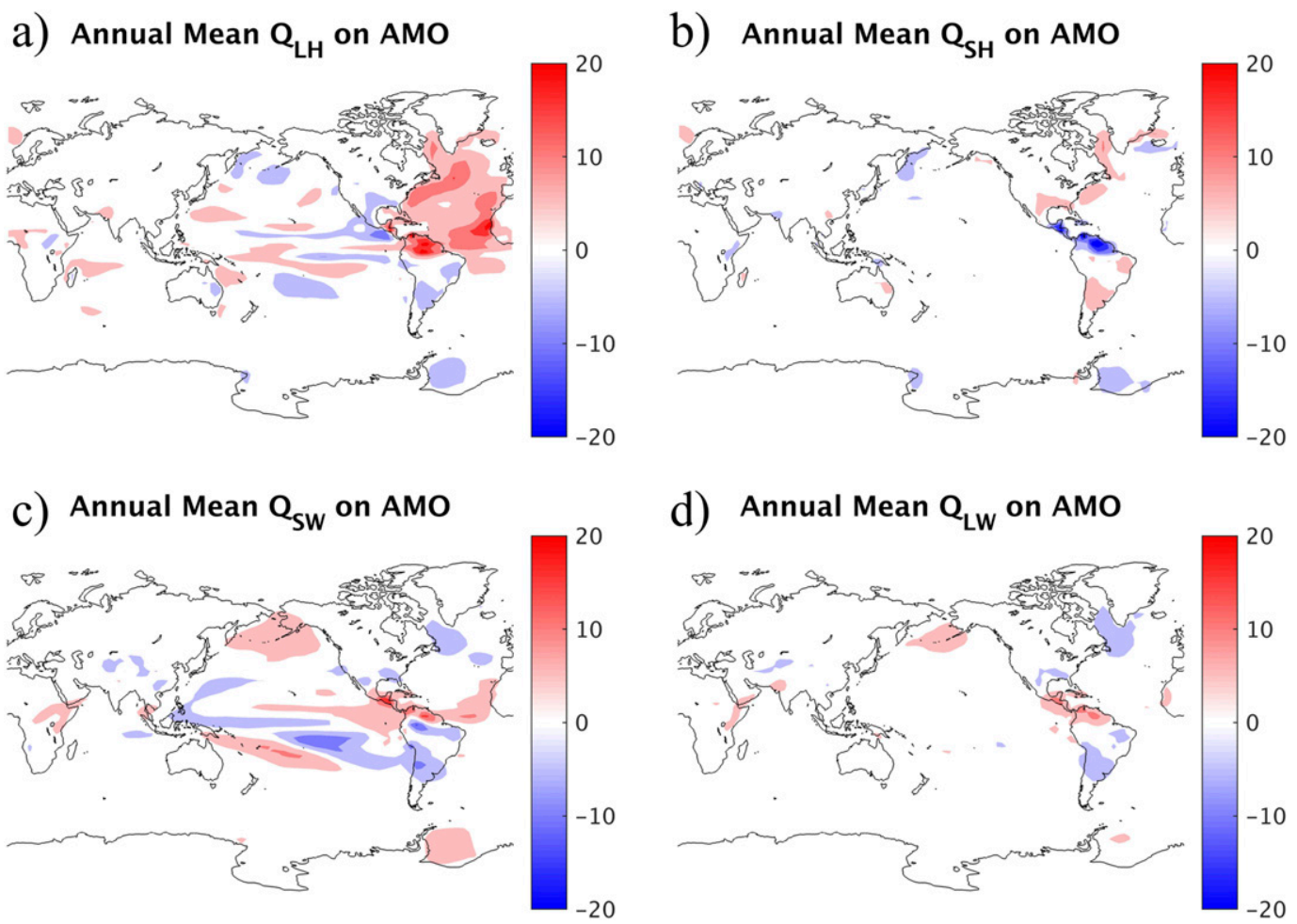

FIG. 12. Regression of (a) latent heat flux $Q_{\mathrm{LH}}\left(\mathrm{W} \mathrm{m}^{-2}\right)$, (b) sensible heat flux $Q_{\mathrm{SH}}\left(\mathrm{W} \mathrm{m}^{-2}\right)$, (c) net shortwave radiation $Q_{\mathrm{SW}}\left(\mathrm{W} \mathrm{m}^{-2}\right)$, and (d) net longwave radiation $Q_{\mathrm{LW}}\left(\mathrm{W} \mathrm{m}^{-2}\right)$ on the AMO. The surface terms are dominated by the latent heat flux changes and balanced mainly by changes to the radiative terms, consistent with changes in clouds. Values are shaded where the regression is at least $95 \%$ significant.

(Fig. 10e) in the region as a result of decreased upperocean mixing during the positive AMO phase.

Further examining the initial hypothesis that the impacts can, to lowest order, be described by the zonally symmetric interhemispheric energy balance theory, we can examine how the zonally asymmetric patterns change lagged from the AMO peak (Fig. 13). Even though the tropical salinity from the proxy record and the model simulation peak 10 years after the AMO maximum, like the Hadley circulation in Fig. 7, the overall change in tropical precipitation and atmospheric cross-equatorial transport is significantly reduced at 10 years following the peak of the AMO, compared with the anomalies at the peak of the AMO. The SST pattern at $\mathrm{AMO}+10 \mathrm{yr}$ is similar spatially but weaker in magnitude than at the AMO maximum, with generally positive Northern Hemisphere anomalies and negative Southern Hemisphere anomalies. The changes in net atmospheric energy are mainly driven by enhanced surface fluxes and correspond with the SST anomalies and the areas of oceanic heat uptake at lag 0. Combined, these results are suggestive that the atmosphere is responsible for most of the global adjustment to the AMO SST forcing. The extratropical impacts and energy balance are initially driven by the atmospheric response to the shifts in the ITCZ.

\section{e. North Atlantic versus tropical Atlantic forcing}

The respective roles of the extratropical and tropical North Atlantic as the driving force for AMO impacts and, for the recent decade-and-a-half, tropical Pacific cooling have been much discussed (Sutton and Hodson 2007; McGregor et al. 2014; Li et al. 2015b). Therefore, additional experiments are designed to test the efficacy of different regions of the Atlantic for forcing the tropical Pacific, confining the AMO anomalies to the northern extratropical Atlantic $\left(40^{\circ}-70^{\circ} \mathrm{N}\right)$ or the tropical Atlantic $\left(0^{\circ}-30^{\circ} \mathrm{N}\right)$ (the two boxes in Fig. 4) while the rest of the North Atlantic is allowed to evolve freely. We call these two versions of the AMO "40N AMO" and "tropical AMO," respectively. These additional experiments are all run for 400 years.

From these simulations, we can see that the forcing by the tropical AMO is important for modifying the energy balance between the hemispheres (Fig. 14). The warmer SSTs in the tropical Atlantic during the positive phase of the AMO force additional convection in the tropical Atlantic, which enhances the Walker circulation 
a) AMO leads 10y Annual Mean P-E \& U

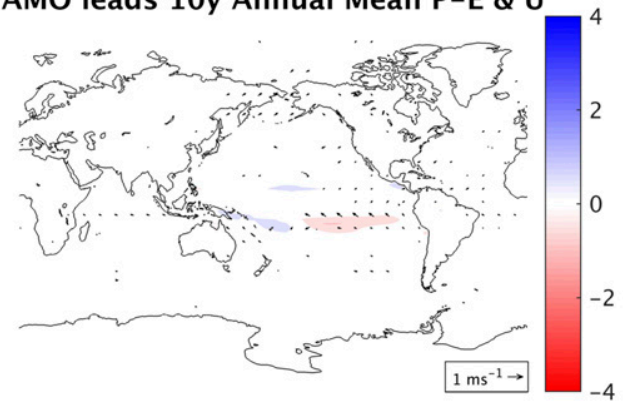

C)

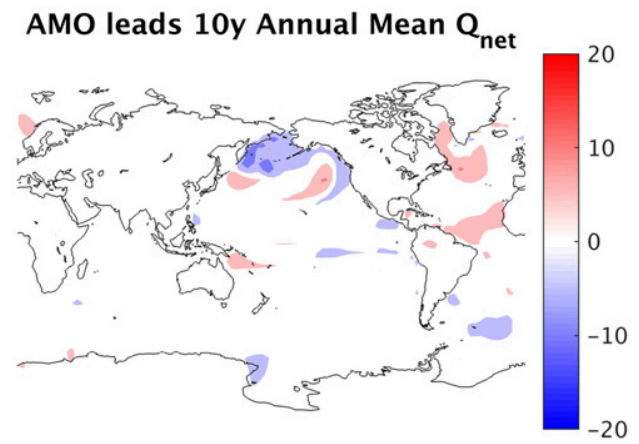

b)

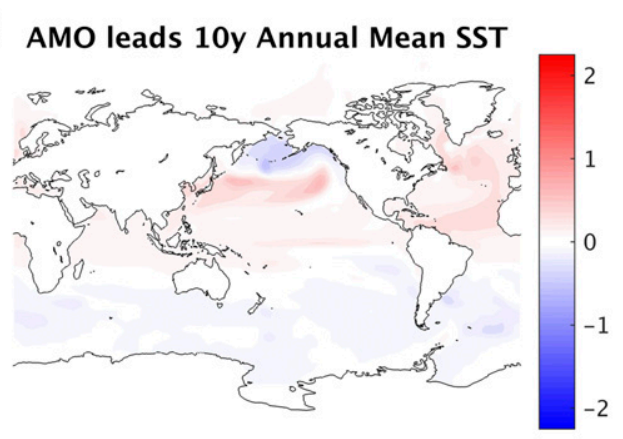

d) AMO leads 10y Annual Mean $Q_{\text {sfc }}$

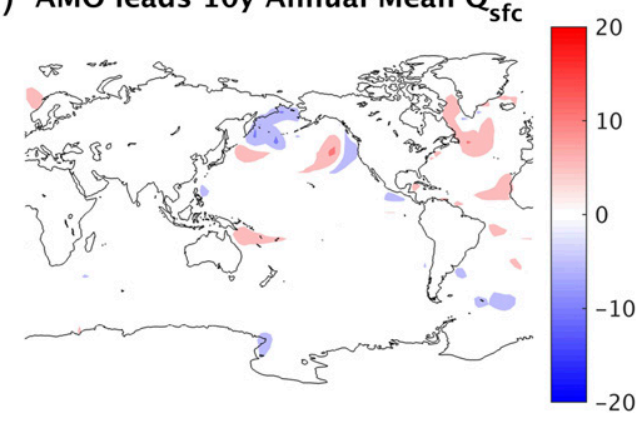

Fig. 13. Regression of annual mean (a) $P-E\left(\mathrm{~mm} \mathrm{day}^{-1}\right)$ and surface-850-hPa winds $U$, (b) SST $\left({ }^{\circ} \mathrm{C}\right)$, (c) $Q_{\text {net }}\left(\mathrm{W} \mathrm{m}^{-2}\right)$, and (d) $Q_{\text {sfc }}\left(\mathrm{W} \mathrm{m}^{-2}\right)$ with the AMO leading by $10 \mathrm{yr}$. The lagged regressions are spatially consistent but overall weaker than the lag-0 regressions, suggesting that the quick ITCZ response is the dominant mechanism of adjustment to the AMO. Values are shaded where the regression is at least $95 \%$ significant.

(Li et al. 2015b) and cross-equatorial flow (McGregor et al. 2014), with opposite tendencies during the negative AMO. This results in a similar pattern of winds and precipitation changes in the tropical Pacific as when the AMO is imposed over the whole North Atlantic (Fig. 14a). The changes in the tropical Indian Ocean and the extratropical Pacific responses are more muted in the tropical AMO case. This differs from the 40N AMO simulation, where the main tropical response in $P-E$ is the development of a dipole over the western Pacific warm pool and Maritime Continent region and a strengthening on of the Walker circulation (Fig. 14b).

The energetics of the difference in forcing from the two regions shows differences consistent with the Northern Hemisphere forcing an ITCZ shift in the tropical AMO case but not in the 40N AMO case. In the tropical AMO case, the net atmospheric heating is large and positive between $0^{\circ}$ and $30^{\circ} \mathrm{N}$, which is compensated both to the north and the south (Fig. 14e). The compensation to the south accounts for a greater hemispheric energy imbalance between the two hemispheres, forcing the ITCZ farther into the Northern Hemisphere, as seen in the precipitation shifts in the tropical Pacific. In contrast, in the $40 \mathrm{~N}$ AMO forced simulation, the net atmospheric heating that occurs between $40^{\circ}$ and $70^{\circ} \mathrm{N}$ produces less heating over the whole of the Northern Hemisphere and no major response in the Southern Hemisphere (Fig. 14f). As a result, the energy imbalance between the two hemispheres is much smaller by comparison, with a similarly small ITCZ shift and a zonally asymmetric precipitation response with zero in the zonal mean (Tables 2 and 3). The much weaker impacts in the Southern Hemisphere of the 40N AMO forced simulation are consistent with the findings of Li et al. (2014).

\section{Summary and discussion}

The tropical Pacific Ocean shows changes in mean state on multidecadal time scales resulting from the AMO. The gradient of the SST between the tropical Atlantic and Pacific modifies the Walker circulation in the atmosphere. The modified Walker circulation is reflected as a change in the trade wind strength in the equatorial Pacific. The salinity at Palmyra reflects changes in upwelling strength in the equatorial Pacific cold tongue, as well as locally forced changes in evaporation driven by the changes in the trade wind strength. As tracked by changes in the $\delta^{18} \mathrm{O}_{\text {sw }}$ in an extended coral record from Palmyra Atoll, the salinity varies with a 
a)

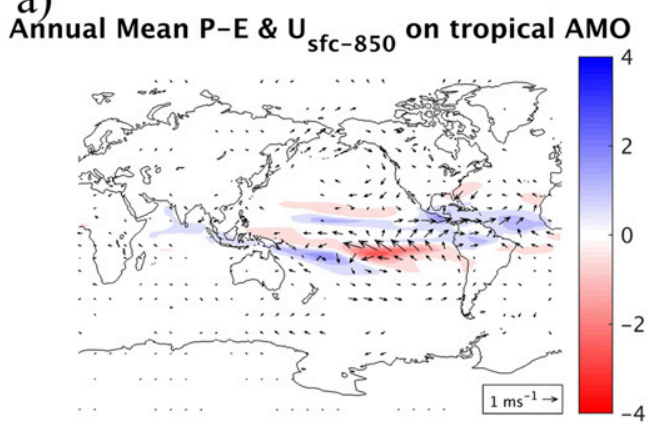

c) Annual Mean $Q_{\text {net }}$ on Tropical AMO

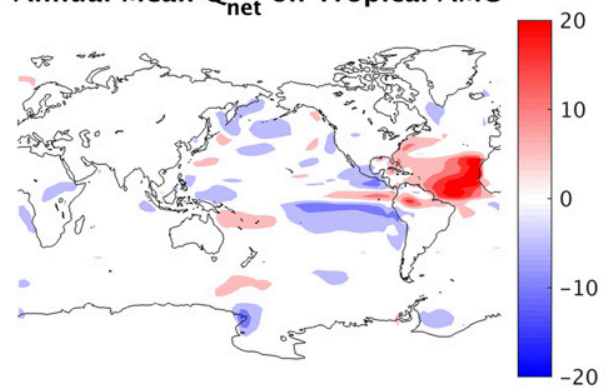

e)

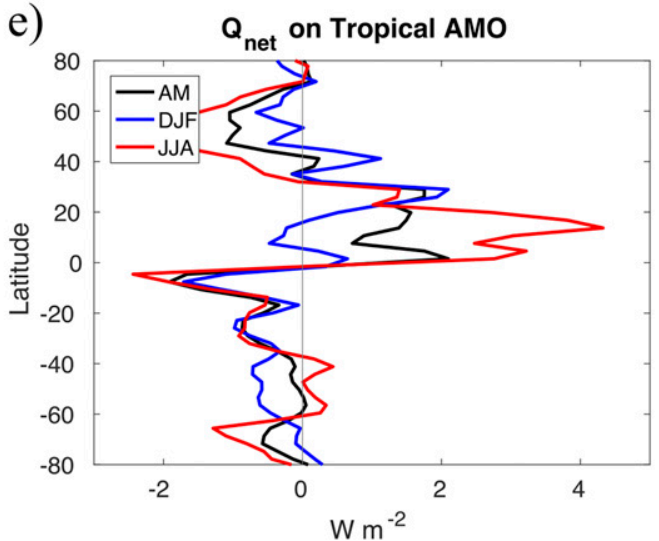

b)

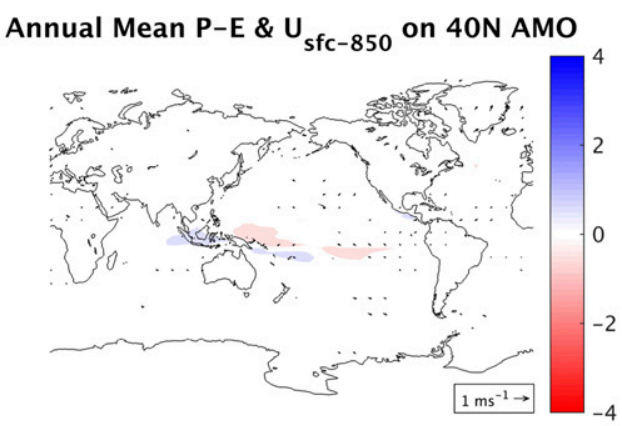

d)

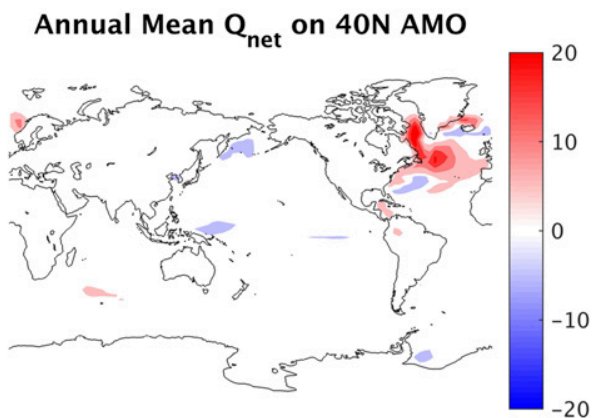

f)

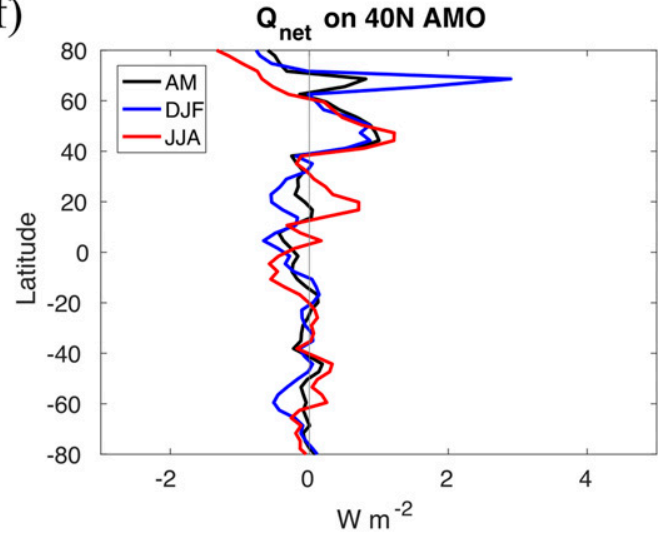

FIG. 14. Regression of (a),(b) $P-E\left(\mathrm{~mm} \mathrm{day}^{-1}\right)$ and surface-850-hPa winds and (c),(d) $Q_{\text {net }}\left(\mathrm{W} \mathrm{m}^{-2}\right)$ on tropical AMO and 40N AMO, respectively. (e),(f) Zonally averaged results from (c),(d), respectively. Values are shaded where the regression is at least $95 \%$ significant.

10-yr lag to the AMO. These changes are also reflected in changes to the ITCZ in the north tropical Pacific.

Given the observed changes in the tropical Pacific trade winds and circulation resulting from changes in the AMO, we take the opportunity to evaluate the extent to which these observations agree with the theory that the ITCZ shifts toward the warmer hemisphere. During the positive phase of the AMO, significantly greater surface heating of the atmosphere from the ocean occurs in the North Atlantic. Using a coupled model in an AMO pacemaker experiment, we find that during the warm phase of the AMO, enhanced precipitation in the tropical North Atlantic enhances the Pacific trade winds. These changes in the Pacific trade winds, particularly the crossequatorial component of the southeasterly trades, enhance the equatorial Pacific cold tongue and drive the Pacific ITCZ farther into the Northern Hemisphere and a drying of the Southern Hemisphere tropical Pacific

TABLE 2. As in Table 1, but for 40N AMO.

\begin{tabular}{lrcr}
\hline & All years & AMO positive & AMO negative \\
\hline Global & 0.2 & 0.2 & 0.2 \\
Northern Hemisphere & -0.5 & -0.6 & -0.6 \\
Southern Hemisphere & 0.9 & 1.0 & 1.0 \\
Difference & -1.4 & -1.6 & -1.6
\end{tabular}


TABLE 3. As in Table 1, but for tropical AMO.

\begin{tabular}{lrcc}
\hline \hline & All years & AMO positive & AMO negative \\
\hline Global & 0.2 & 0.2 & 0.2 \\
Northern Hemisphere & -0.4 & 0.4 & -1.2 \\
Southern Hemisphere & 0.8 & 0.0 & 1.6 \\
Difference & -1.2 & 0.4 & -2.8 \\
\hline
\end{tabular}

(Fig. 15). This is consistent with the observed increase in salinity at Palmyra. These changes are reversed during the negative phase of the AMO.

We can also calculate the atmospheric energy balance within the model. We find that the changes in precipitation follow a similar relationship to the hemispheric energy imbalance calculations over the seasonal cycle. The changes in atmospheric energy balance are mostly surface changes, with the two dominant surface energy budget terms being latent heat flux and shortwave radiative flux. We also find that the ocean circulation changes to partially compensate for the hemispheric energy imbalance on these time scales.

Recent research has shown the connection between the different ocean basins, particularly in the tropics, over longer interannual and decadal time scales (McGregor et al. 2014; Li et al. 2015b; Chikamoto et al. 2015). Here, we add to these findings by showing this relationship of the Atlantic to the tropical Pacific using a proxy record. The $\delta^{18} \mathrm{O}_{\mathrm{sw}}$ has significant potential to provide even longer records in the central tropical Pacific from the ongoing collection and analysis efforts. The explanation that we provide here for the proxy signal should be examined for longer Pacific coral as they become available to further enhance our understanding of climate variability over the recent past.
Sachs et al. (2009) found a southward shift of the ITCZ in the central Pacific during the Little Ice Age and hypothesized that it could be related to the cooling of the Northern Hemisphere tropics, which was consistent with other proxies globally for that period. Likewise, we find that the central Pacific ITCZ shifts in response to both the tropical and extratropical Atlantic forcing, although the shift is much stronger in response to the tropical than to the extratropical forcing in this model. Interrelated with the shift of the ITCZ are the changes in the Pacific trade winds. Considering the extent of the trade wind changes in the Pacific, it would not be surprising to find that the localized Pacific shifts that we observe in the proxy record extend zonally across the Pacific and presumably in the zonal mean as well. This inference is supported by the changes to the zonally averaged vertical motion from reanalysis at the same time as the changes in salinity in Palmyra and in agreement with tropical Atlantic forcing of the tropical Pacific salinity found by Zanchettin et al. (2016).

Unlike many previous studies, we use a fully coupled ocean to examine the changes to the tropical Pacific ITCZ given a zonally asymmetric hemispheric forcing. In agreement with Kay et al. (2016), we find that the ocean transport does account for some of the energy transfer. However, this study still sees substantial modification of the ITCZ remotely. A major difference between our study and the Kay et al. (2016) study is the location of the forcing. In this study, the forcing is a simulated AMO with surface forcing across the Atlantic in the Northern Hemisphere, whereas in Kay et al. (2016) the shortwave radiation is modified mainly in the Southern Hemisphere and is zonally symmetric. The findings for the extratropical AMO forcing are more similar to Kay et al.

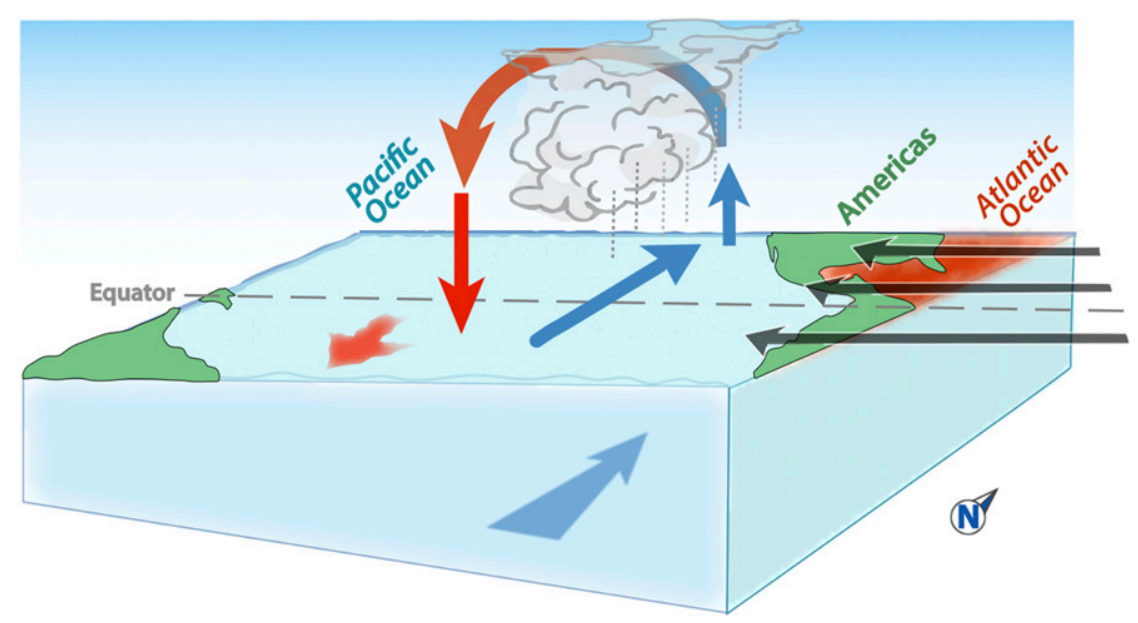

FIG. 15. Schematic diagram summarizing how warm Atlantic SSTs can impact the precipitation and hemispheric energy balance in the Pacific. 
(2016). Another possible explanation for the differences between this study and Kay et al. (2016) is the difference between the ocean basins. We only examine the Pacific currents for interhemispheric transport because the forcing is imposed in the Atlantic sector. However there are large differences in cross-hemispheric energy transport in the mean states of the different ocean basins from the thermohaline circulation.

We also note that the nature of the relationship between the AMO and the Atlantic meridional overturning circulation (AMOC) is under investigation (Clement et al. 2015; Delworth and Zeng 2016). Because of the differential surface heating provided by the AMOC, the ITCZ shifts into the same hemisphere as the deep water creation (Frierson et al. 2013; Marshall et al. 2014), and the AMOC acts to transport energy from one hemisphere to the other. These results suggest that the changes between the latitude of the ITCZ and the strength of the AMOC could be linked through AMO-like surface variability, particularly for the tropical Atlantic portion of the AMO.

Changes in the Atlantic lead to changes in the tropical Pacific, which can then impact the extratropical Pacific (Di Lorenzo et al.2015) and Atlantic. The changes in the extratropical Pacific seem to have an impact again on the North Atlantic (López-Parages and Rodríguez-Fonseca 2012; Zanchettin et al. 2008). This leads to a potential feedback loop across the different basins on long multidecadal time scales. These interactions need to be better understood through additional experiments, but it should be acknowledged that given the impact of shorter time scale noise and other competing influences, this feedback is likely significantly attenuated by the time the full cycle is complete.

Acknowledgments. The authors thank three anonymous reviewers for their insightful comments. This research was performed while A. F. Z. L. held a National Research Council Associateship Award at NOAA/ PMEL. M. J. M. is supported by NOAA. DMWF is supported by NSF Grants AGS-1359464 and PLR1341497. The authors thank Karen Birchfeld for her assistance with the figures. The reanalysis data used in this study are the Twentieth Century Reanalysis Project version 2c provided by the NOAA/OAR/ESRL PSD, Boulder, Colorado (online at https://www.esrl.noaa.gov/psd/data/ 20thC_Rean/). Support for the Twentieth Century Reanalysis Project version $2 \mathrm{c}$ dataset is provided by the U.S. Department of Energy, Office of Science Biological and Environmental Research (BER), and by the National Oceanic and Atmospheric Administration Climate Program Office. The AMO index (Enfield et al. 2001) can be downloaded from http://www.esrl.
noaa.gov/psd/data/timeseries/AMO/. The Palmyra coral $\mathrm{Sr} / \mathrm{Ca}$-derived SSTs are documented in Nurhati et al. (2011) and available for download at ftp://ftp.ncdc. noaa.gov/pub/data/paleo/coral/east_pacific/palmyra2011. txt. Model simulations and MATLAB code available from A. F. Z. L. upon request. This is PMEL Contribution 4691.

\section{REFERENCES}

Chikamoto, Y., and Coauthors, 2015: Skilful multi-year predictions of tropical trans-basin climate variability. Nat. Commun., 6 , 6869, https://doi.org/10.1038/ncomms7869.

Clement, A., K. Bellomo, L. N. Murphy, M. A. Cane, T. Mauritsen, G. Rädel, and B. Stevens, 2015: The Atlantic multidecadal oscillation without a role for ocean circulation. Science, $\mathbf{3 5 0}$, 320-324, https://doi.org/10.1126/science.aab3980.

Compo, G. P., and Coauthors, 2011: The Twentieth Century Reanalysis Project. Quart. J. Roy. Meteor. Soc., 137, 1-28, https:// doi.org/10.1002/qj.776.

Delcroix, T., S. Cravatte, and M. J. McPhaden, 2007: Decadal variations and trends in tropical Pacific sea surface salinity since 1970. J. Geophys. Res., 112, C03012, https://doi.org/ 10.1029/2006JC003801.

Delworth, T. L., and F. Zeng, 2016: The impact of the North Atlantic Oscillation on climate through its influence on the Atlantic meridional overturning circulation. J. Climate, 29, 941-962, https://doi.org/10.1175/JCLI-D-15-0396.1.

- — - L. Zhang, R. Zhang, G. A. Vecchi, and X. Yang, 2017: The central role of ocean dynamics in connecting the North Atlantic Oscillation to the extratropical component of the Atlantic multidecadal oscillation. J. Climate, 30, 3789-3805, https://doi.org/10.1175/JCLI-D-16-0358.1.

Di Lorenzo, E., G. Liguori, N. Schneider, J. Furtado, B. Anderson, and M. Alexander, 2015: ENSO and meridional modes: A null hypothesis for Pacific climate variability. Geophys. Res. Lett., 42, 9440-9448, https://doi.org/10.1002/2015GL066281.

Ding, Q., E. J. Steig, D. S. Battisti, and J. M. Wallace, 2012: Influence of the tropics on the southern annular mode. J. Climate, 25, 6330-6348, https://doi.org/10.1175/JCLI-D-11-00523.1.

Donohoe, A., J. Marshall, D. Ferreira, K. Armour, and D. McGee, 2014: The interannual variability of tropical precipitation and interhemispheric energy transport. J. Climate, 27, 3377-3392, https://doi.org/10.1175/JCLI-D-13-00499.1.

Enfield, D. B., A. M. Mestas-Nuñez, and P. J. Trimble, 2001: The Atlantic multidecadal oscillation and its relation to rainfall and river flows in the continental U.S. Geophys. Res. Lett., 28, 2077-2080, https://doi.org/10.1029/2000GL012745.

Fairbanks, R., M. Evans, J. Rubenstone, R. Mortlock, K. Broad, M. Moore, and C. Charles, 1997: Evaluating climate indices and their geochemical proxies measured in corals. Coral Reefs, 16, S93-S100, https://doi.org/10.1007/s003380050245.

Frierson, D. M., and Y.-T. Hwang, 2012: Extratropical influence on ITCZ shifts in slab ocean simulations of global warming. J. Climate, 25, 720-733, https://doi.org/10.1175/JCLI-D-11-00116.1.

_ , and Coauthors, 2013: Contribution of ocean overturning circulation to tropical rainfall peak in the Northern Hemisphere. Nat. Geosci., 6, 940-944, https://doi.org/10.1038/ ngeo1987.

Fučkar, N. S., S.-P. Xie, R. Farneti, E. A. Maroon, and D. M. Frierson, 2013: Influence of the extratropical ocean circulation on the intertropical convergence zone in an idealized coupled general 
circulation model. J. Climate, 26, 4612-4629, https://doi.org/ 10.1175/JCLI-D-12-00294.1.

Galbraith, E. D., and Coauthors, 2011: Climate variability and radiocarbon in the CM2Mc Earth System Model. J. Climate, 24, 4230-4254, https://doi.org/10.1175/2011JCLI3919.1.

Giese, B. S., and S. Ray, 2011: El Niño variability in Simple Ocean Data Assimilation (SODA), 1871-2008. J. Geophys. Res., 116, C02024, https://doi.org/10.1029/2010JC006695.

He, J., and B. J. Soden, 2016: Does the lack of coupling in SST-forced atmosphere-only models limit their usefulness for climate change studies? J. Climate, 29, 4317-4325, https://doi.org/ 10.1175/JCLI-D-14-00597.1.

Held, I. M., 2001: The partitioning of the poleward energy transport between the tropical ocean and atmosphere. J. Atmos. Sci., 58, 943-948, https://doi.org/10.1175/1520-0469(2001)058<0943: TPOTPE $>2.0 . \mathrm{CO} ; 2$.

Kang, S. M., I. M. Held, and S.-P. Xie, 2014: Contrasting the tropical responses to zonally asymmetric extratropical and tropical thermal forcing. Climate Dyn., 42, 2033-2043, https:// doi.org/10.1007/s00382-013-1863-0.

Kay, J. E., C. Wall, V. Yettella, B. Medeiros, C. Hannay, P. Caldwell, and C. Bitz, 2016: Global climate impacts of fixing the Southern Ocean shortwave radiation bias in the Community Earth System Model (CESM). J. Climate, 29, 4617-4636, https://doi.org/10.1175/JCLI-D-15-0358.1.

Kerr, R. A., 2000: A North Atlantic climate pacemaker for the centuries. Science, 288, 1984-1985, https://doi.org/10.1126/ science.288.5473.1984.

Knight, J. R., R. J. Allan, C. K. Folland, M. Vellinga, and M. E. Mann, 2005: A signature of persistent natural thermohaline circulation cycles in observed climate. Geophys. Res. Lett., 32, L20708, https://doi.org/10.1029/2005GL024233.

, C. K. Folland, and A. A. Scaife, 2006: Climate impacts of the Atlantic multidecadal oscillation. Geophys. Res. Lett., 33, L17706, https://doi.org/10.1029/2006GL026242.

Landu, K., L. R. Leung, S. Hagos, V. Vinoj, S. A. Rauscher, T. Ringler, and M. Taylor, 2014: The dependence of ITCZ structure on model resolution and dynamical core in aquaplanet simulations. J. Climate, 27, 2375-2385, https://doi.org/ 10.1175/JCLI-D-13-00269.1.

Li, X., D. M. Holland, E. P. Gerber, and C. Yoo, 2014: Impacts of the north and tropical Atlantic Ocean on the Antarctic Peninsula and sea ice. Nature, 505, 538-542, https://doi.org/ 10.1038/nature12945.

— E. E. P. Gerber, D. M. Holland, and C. Yoo, 2015a: A Rossby wave bridge from the tropical Atlantic to West Antarctica. J. Climate, 28, 2256-2273, https://doi.org/10.1175/JCLI-D-14-00450.1.

_ , S.-P. Xie, S. T. Gille, and C. Yoo, 2015b: Atlantic-induced pantropical climate change over the past three decades. Nat. Climate Change, 6, 275-279, https://doi.org/10.1038/nclimate2840.

López-Parages, J., and B. Rodríguez-Fonseca, 2012: Multidecadal modulation of El Niño influence on the Euro-Mediterranean rainfall. Geophys. Res. Lett., 39, L02704, https://doi.org/ 10.1029/2011g1050049.

Marshall, J., A. Donohoe, D. Ferreira, and D. McGee, 2014: The ocean's role in setting the mean position of the inter-tropical convergence zone. Climate Dyn., 42, 1967-1979, https://doi.org/ 10.1007/s00382-013-1767-z.

McGregor, S., A. Timmermann, M. F. Stuecker, M. H. England, M. Merrifield, F.-F. Jin, and Y. Chikamoto, 2014: Recent Walker circulation strengthening and Pacific cooling amplified by Atlantic warming. Nat. Climate Change, 4, 888-892, https:// doi.org/10.1038/nclimate2330.
Nurhati, I. S., K. M. Cobb, and E. Di Lorenzo, 2011: Decadal-scale SST and salinity variations in the central tropical Pacific: Signatures of natural and anthropogenic climate change. J. Climate, 24, 3294-3308, https://doi.org/10.1175/2011JCLI3852.1.

Picaut, J., M. Ioualalen, T. Delcroix, F. Masia, R. Murtugudde, and J. Vialard, 2001: The oceanic zone of convergence on the eastern edge of the Pacific warm pool: A synthesis of results and implications for El Niño-Southern Oscillation and biogeochemical phenomena. J. Geophys. Res., 106, 2363-2386, https://doi.org/10.1029/2000JC900141.

Ruprich-Robert, Y., R. Msadek, F. Castruccio, S. Yeager, T. Delworth, and G. Danabasoglu, 2017: Assessing the climate impacts of the observed Atlantic multidecadal variability using the GFDL CM2.1 and NCAR CESM1 global coupled models. J. Climate, 30, 2785-2810, https://doi.org/10.1175/ JCLI-D-16-0127.1.

Sachs, J. P., D. Sachse, R. H. Smittenberg, Z. Zhang, D. S. Battisti, and S. Golubic, 2009: Southward movement of the Pacific intertropical convergence zone AD 1400-1850. Nat. Geosci., 2, 519-525, https://doi.org/10.1038/ngeo554.

Semenov, V. A., M. Latif, D. Dommenget, N. S. Keenlyside, A. Strehz, T. Martin, and W. Park, 2010: The impact of North Atlantic-Arctic multidecadal variability on Northern Hemisphere surface air temperature. J. Climate, 23, 5668-5677, https://doi.org/10.1175/2010JCLI3347.1.

Sutton, R. T., and D. L. Hodson, 2005: Atlantic Ocean forcing of North American and European summer climate. Science, $\mathbf{3 0 9}$, 115-118, https://doi.org/10.1126/science.1109496.

— and - 2007: Climate response to basin-scale warming and cooling of the North Atlantic Ocean. J. Climate, 20, 891-907, https://doi.org/10.1175/JCLI4038.1.

Timmermann, A., and Coauthors, 2007: The influence of a weakening of the Atlantic meridional overturning circulation on ENSO. J. Climate, 20, 4899-4919, https://doi.org/10.1175/JCLI4283.1.

Ting, M., Y. Kushnir, R. Seager, and C. Li, 2009: Forced and internal twentieth-century SST trends in the North Atlantic. J. Climate, 22, 1469-1481, https://doi.org/10.1175/2008JCLI2561.1.

Trenberth, K. E., and D. J. Shea, 2006: Atlantic hurricanes and natural variability in 2005. Geophys. Res. Lett., 33, L12704, https://doi.org/10.1029/2006GL026894.

Trossman, D., J. Palter, T. Merlis, Y. Huang, and Y. Xia, 2016: Large-scale ocean circulation-cloud interactions reduce the pace of transient climate change. Geophys. Res. Lett., $\mathbf{4 3}$, 3935-3943, https://doi.org/10.1002/2016GL067931.

Wang, C., S.-K. Lee, and C. R. Mechoso, 2010: Interhemispheric influence of the Atlantic warm pool on the southeastern Pacific. J. Climate, 23, 404-418, https://doi.org/10.1175/2009JCLI3127.1.

Zanchettin, D., S. W. Franks, P. Traverso, and M. Tomasino, 2008: On ENSO impacts on European wintertime rainfalls and their modulation by the NAO and the Pacific multi-decadal variability described through the PDO index. Int. J. Climatol., 28, 995-1006, https://doi.org/10.1002/joc.1601.

_, O. Bothe, H. F. Graf, N.-E. Omrani, A. Rubino, and J. H. Jungclaus, 2016: A decadally delayed response of the tropical Pacific to Atlantic multidecadal variability. Geophys. Res. Lett., 43, 784 792, https://doi.org/10.1002/2015GL067284.

Zhang, R., and T. L. Delworth, 2006: Impact of Atlantic multidecadal oscillations on India/Sahel rainfall and Atlantic hurricanes. Geophys. Res. Lett., 33, L17712, https://doi.org/ 10.1029/2006GL026267.

— tion on North Pacific climate variability. Geophys. Res. Lett., 34, L23708, https://doi.org/10.1029/2007GL031601. 